\title{
SOSIALISASI PENANGANAN KONFLIK SOSIAL DI KELURAHAN KLAWUYUK KOTA SORONG
}

\author{
Aram Palilu* \\ Fakultas Ilmu Sosial Universitas Victory Sorong \\ arampalilu1015@gmail.com
}

\begin{abstract}
ABSTRAK
Konflik sosial selalu ada, disebabkan karena adanya perbedaan-perbedaan kepentingan dari individu-individu dan kelompok-kelompok maupun persoalan dibidang SARA (Suku, Agama, dan Ras); politik, ekonomi serta menyangkut sosial dan budaya. Karena itu, bagaimana dikelola/dikontrol didalam penanganannya agar tidak berdampak gejolak atau mengarah pada kekerasan fisik, kehilangan harta adanya korban jiwa. Penanganan konflik yang efektif tentu menetralisir tingkat intensitas konflik ke arah terciptanya suasana yang harmonis, tenteram, aman dan sejahtera.Motode yang digunakan dalam kegiatan pengabdian pada masyarakat ini adalah pendidikan masyarakat. Tahapan penyuluhan terdiri dari studi pendahuluan, pemaparan materi, dan evaluasi. Kegiatan penyuluhan melalui sosialisasi tentang penanganan konflik sosial ditujukan kepada khalayak sasaran. Tingkat keberhasilan sosialisasi ini ditentukan oleh adanya perbedaan pemahaman dan pengetahuan mengenai penanganan konflik yang belum baik dengan sesudah pelaksanaan sosialisasi, dimana adanya pemahaman dan pengetahuan yang lebih komprehensif dan terintegral.
\end{abstract}

Kata kunci: Konflik Sosial, Pencegahan Konflik, Penghentian Konflik, dan Pemulihan Pascakonflik.

\begin{abstract}
There is always social conflict, caused by differences in the interests of individuals and groups as well as problems in the field of SARA (Tribe, Religion, and Race); politics, economics, and social and cultural issues. Therefore, how to be managed/controlled in its handling so as not to cause turmoil or lead to physical violence, loss of property of casualties. Effective conflict management certainly neutralizes the intensity of the conflict towards creating a harmonious, peaceful, safe and prosperous atmosphere. The method used in community service activities is community education. The stages of counseling consist of preliminary studies, material presentations, and evaluations. Extension activities through socialization of handling social conflicts are aimed at the target audience. The level of success of this socialization is determined by the existence of differences in understanding and knowledge about handling conflicts that have not been good with after the implementation of socialization, where there are a more comprehensive and integrated understanding and knowledge.
\end{abstract}

Keyword: Social conflict, Conflict Prevention, Post-Conflict Recovery 


\section{PENDAHULUAN}

Sejak masyarakat manusia mulai dari bentuknya yang primitif secara relatif tidak berbeda satu sama lain, masyarakat itu tetap mempunyai perbedaan-perbedaan fundamental antara golongan yang bertikai di dalam mengejar kepentingan masing-masing golongannya. Manusia adalah makhluk sosial yang senantiasa bergantung pada orang lain dalam memenuhi keperluan hidupnya. Disadari atau tidak, kita semua memiliki sifat saling membutuhkan yang begitu kuat. Kebutuhan manusia dapat dipenuhi ketika antara manusia yang satu dan yang lain memiliki kesadaran dan penghormatan terhadap hak-hak orang lain.

Menurut para pakar (Giay, 1995), manusia dalam tingkat sosial apapun mewarisi sesuatu yang merupakan pegangan hidup, suatu keprihatinan yang mendasar (an ultimate concern). Setiap orang berusaha mempertahankan apa yang diyakininya dan bersedia mati demi keyakinannya itu (Fowler, 1976). Sesungguhnya sejarah peradaban manusia adalah merupakan catatan terhadap perkembangan pertumbuhan dan perubahan yang dicapai manusia dalam menjawab setiap persoalan (konflik) yang dihadapi manusia adalah kehidupan manusia itu sendiri bersama orang dan sesuatu yang lain. Usaha manusia semacam itu, dalam satu segi merupakan proses yang berlangsung terus-menerus, sejalan dengan berlangsungnya proses keberadaan manusia. Proses itu merupakan petunjuk dan bukti sejarah terhadap kehidupan dan daya kreatif manusia (Baker, 1972).

Di tengah-tengah masyarakat kita sering terjadi kondisi nyata yang menunjukkan adanya perbedaan dengan orang lain. Perbedaan-perbedaan itu sebenarnya hal yang sangat lumrah. Namun, perbedaan sering menimbulkan konflik dalam masyarakat. Apabila konflik tersebut tidak dapat dikendalikan, maka akan menimbulkan tindak kekerasan. Begitu pula konflik yang terjadi, pada mulanya bersifat individual, namun karena kepandaian mereka menghidupkan solidaritas atas ikatan-ikatan baku, maka konflik berubah menjadi massal (Anonim, 2011).

Dalam kehidupan bermasyarakat, berbagai jenis konflik adalah suatu keniscayaan. Suatu masyarakat pasti pernah mengalami konflik, baik antara anggotanya maupun dengan kelompok masyarakat lain. Istilah konflik sering mengandung pengertian negatif, sebab cenderung dimaknai sebagai lawan kata dari keserasian, kedamaian, dan keteraturan. Konflik sering pula diasosiasikan dengan ancaman ataupun penggunaan kekerasan. Padahal jika dikelola dengan baik, konflik tidak selamanya diakhir dengan kekerasan.Penangan konflik sosial bagi yang berwenang selama ini bersifat parsial, sehingga konflik biasanya 
berkepanjangan/berlarut-larut dan pada kondisi tertentu dapat berakibat lebih fatal bagi keamanan maupun ketentraman masyarakat.

Hal ini terjadi karena adanya benturan akibat pertemuan antara dua atau lebih nilai-nilai hidup ataupun budaya yang relatif berbeda. Dalam keadaan tertentu maka salah satunya akan muncul sebagai nilai-nilai hidup yang menang dan bila tidak terkontrol dapat menciptakan konflik yang fatal.Toffler (1977) menyebut konflik seperti ini "future shock" yakni suatu tantangan perubahan yang terjadi di negerinya sendiri yang merupakan penyakit yang lebih parah daripada culture shock. Dan pada tataran tertentu dapat menyebabkan pertikaian sebagai gejala yang tidak mungkin dihindari dalam masyarakat. Struktur sosial dilihatnya sebagai gejala yang mencakup berbagai proses asosiatif dan disosiatif yang tidak mungkin terpisah-pisahkan, namun dapat dibedakan dalam analisis (Bernstein, 1981).

Hal demikian dipertegas oleh Randall Collins, dimana membagi apa yang mikro dan apa yang makro. Mikro sosial berarti hubungan interaksi antarindividu dalam masyarakat, sementara makrososial berarti hasil dari interaksi antarindividu dalam masyarakat tersebut. .Menurutnya, konflik merupakan proses sentral dalam kehidupan sosial. Oleh karena itu, konflik tidak dianggap baik maupun buruk. Setiap orang memiliki sifat sosial, maka kemungkinan berkonflik akan selalu ada. Hal itu dikarenakan, setiap orang memiliki kepentingan-kepentingan sendiri.

Berkaitan dengan itu, jika persoalan dan pengertian yang dihadapi manusia berhubungan dengan cara hidupnya dan cara beradanya yang tidak terkontrol, maka persoalan itu akan menjadi semakin kompleks sehingga menjurus kepada pertentangan yang sangat tajam. Ketajaman perbedaan itu, akan menjadi malapetaka bagi manusia jika memasuki tingkat dan dunia politis. Dalam konteks masyarakat multikultural, upaya mencegah konflik dan adanya anggapan bahwa berkonflik merupakan hal negatif adalah sama sekali tidak relevan. Konflik bukanlah sesuatu yang dapat dihindari atau disembunyikan, tetap harus diakui keberadaannya, dikelola, dan diubah menjadi kekuatan untuk perubahan yang positif.

Umumnya para pemerhati masalah konflik sosial sependapat bahwa penanganan konflik sosial, ternyata belum memberikan hasil yang signifikan, bahkan yang lebih ironis lagi justru menimbulkan gejolak yang lebih para dan berkepanjangan karena represif. Dengan demikian Penanganan konflik sosial adalah serangkaian kegiatan yang dilakukan secara sistematis dan terencana dalam situasi dan peristiwa baik sebelum, pada saat, maupun 
sesudah terjadi konflik yang mencakup pencegahan konflik, penghentian konflik, dan pemulihan pascakonflik.

Mungkin ada baiknya bila kita mencoba mengkaji dan menelaah topik ini secara lebih komprehensif-terintegral dan proporsional, namun penangannya lebih humanis. Tulisan ini mencoba mendeskripsikan topik dimaksud, yang pada akhirnya diharapkan dapat menempatkan pada proporsi yang sebenarnya. Dengan adanya pemaparan secara runtut mengenai konflik sosial, maka kerangka referensi dan eksperiensi kita akan mudah mengidentifikasi akar masalah dari konflik itu sendiri sehingga dapat dimaksimalkan cara penyelesaiannya secara akurat. Akurasi dari pemecahan yang tepat akan meminimalisir konflik menjadi lebih efisien dan efektif. Oleh karena itu, maka identifikasi dari konflik sosial harus diuraikan khususnya mengenai cara penanganan konflik yang terjadi.

\section{MASALAH}

Berdasarkan studi pendahuluan (berupa tanya jawab, curah pendapat disimpulkan bahwa pemahaman dan pengetahuan para khalayak sasaran masih sangat terbatas. Hal ini terjadi karena sebelumnya belum pernah ada upaya ataupun sosialisasi tentang konflik sosial. Oleh karena itu, masalah yang dirumuskan dalam pengambdian kepada masyarakat adalah sebagai berikut:

a. Sejauhmana pemahaman dan pengetahuan para aparat mengenai konflik sosial yang terjadi sebelumnya?

b. Bagaimanakah upaya penanganan konflik sosial secara komprehensif dan terintegral, agar tidak mengarah pada kekerasan fisik atau pun kerugian harta benda bagi yang sedang bergejolak?

\section{METODE}

Metode yang digunakan dalam kegiatan pengabdian ini adalah metode pendidikan masyarakat. Metode yang digunakan disini bertujuan untuk meningkatkan pemahaman dan pengetahuan kepada khalayak sasaran (aparat kelurahan, aparat keamanan dan Babinsa, Ketua RT/RW, tokoh masyarakat/agama/perempuan/pemuda/mahasiswa, dan beberapa perwakilan masyarakat), sedangkan tahapan yang ditempuh dalam kegiatan pengabdian kepada masyarakat di Kelurahan Klawuyuk adalah sebagai berikut: 


\subsection{Tahap Penjajakan (Studi) Pendahuluan}

Sebelum melakukan kegiatan sosialisasi terlebih dahulu dilakukan penjajakan pendahuluan berupa tanya jawab/curah pendapat dengan beberapa khalayak sasaran upaya untuk mendapatkan informasi mengenai tingkat pemahaman dan pengetahuan terhadap konflik dan cara penyelesaiannya. Berdasarkan hasil penjajakan pendahuluan disimpulkan bahwa pemahaman dan pengetahuan khalayak sasaran masih sangat rendah, sehingga diputuskan untuk menyampaikan materi tentang cara penanganan konflik sosial di Kelurahan Klawuyuk.

\subsection{Tahap Penyampaian Materi Mengenai Penanganan Konflik Sosial}

Adapun materi yang disampaikan dalam kegiatan penyuluhan tentang cara penanganan konflik sosial di Kelurahan Klawuyuk, adalah meliputi:

a. Pencegahan konflik,

b. Penghentian konflik,

c. Pemulihan Pasca-konflik.

Adapun jadwal kegiatan penyuluhan mengenai penangan konflik sosial adalah sebagai berikut:

\begin{tabular}{|c|c|c|}
\hline Hari/Tanggal & Jam & Kegiatan \\
\hline Senin, 07 Mei 2018 & $08.00-08.30$ & Registrasi Peserta \\
\cline { 2 - 3 } & $08.30-09.30$ & Acara Pembukaan \\
\cline { 2 - 3 } & $09.30-12.00$ & Ceramah/Penyampaian Materi \\
\cline { 2 - 3 } & $12.00-13.00$ & Istirahat \\
\cline { 2 - 3 } & $13.00-15.00$ & Diskui/Curah Pendapat \\
\cline { 2 - 3 } & $15.00-$ Selesai & Penutupan \\
\hline
\end{tabular}

\subsection{Tahap Diskusi (Curah Pendapat)}

Adapun teknik yang digunakan untuk mengetahui tingkat pemahaman dan pengetauan dari khalayak sasaran mengenai cara penanganan konflik sosial adalah berupa penyuluhan, ceramah, diskusi, curah pendapat (brain-stormming), dan lain-lain. Tahap ini merupakan upaya membandingkan dengan studi pendahuluan dengan setelah memperoleh penyampaian materi. Berdasarkan hasil pembanding antara studi pendahuluan dengan sesudah 
penyampaian materi maka dapat diketahui sejauh mana tingkat pemahaman dan pengetahuan dari para khalayak sasaran mengenai penanganan konflik sosial.

\section{HASIL DAN PEMBAHASAN}

Penyuluhan mengenai penanganan konflik sosial yang dilakukan di Kelurahan adalah sebagai berikut:

\subsection{Pencegahan konflik}

Kegiatan pencegahan konflik dilakukan dengan cara:

\subsubsection{MemeliharaKondisi Damai dalam Masyarakat}

a. Mengembangkan sikap toleransi dan saling menghormati kebebasan menjalankan ibadah sesuai dengan agama dan kepercayaannya;

b. Menghormati perbedaan suku, bahasa, dan adat istiadat orang lain;

c. Mengakui dan memperlakukan manusia sesuai dengan harkat dan martabatnya;

d. Mengakui persamaan derajat serta persamaan hak dan kewajiban asasi setiap manusia tanpa membedakan suku, keturunan, agama, kepercayaan, jenis kelamin, kedudukan sosial, dan warna kulit;

e. Mengembangkan persatuan Indonesia atas dasar kebhinneka-tunggal-ikaan; dan/atau

f. Menghargai pendapat dan kebebasan orang lain.

\subsubsection{Mengembangkan Sistem Penyelesaian Perselisihan secara Damai}

a. Penyelesaian perselisihan dalam masyarakat dilakukansecara damai.

b. Penyelesaian secara damai sebagaimana dimaksud adalah mengutamakan musyawarah untuk mufakat serta mengikat semua pihak yang bertikai.

\subsubsection{Meredam Potensi Konflik}

a. Melakukan perencanaan dan pelaksanaan pembangunan yang memperhatikan aspirasi masyarakat;

b. Menerapkan menerapkan prinsip tata kelola pemerintahan yang baik;

c. Melakukan program perdamaian di daerah potensi konflik;

d. Mengintensifkan dialog antarkelompok masyarakat;

e. Menegakkan hukum tanpa diskriminasi;

f. Membangun karakter bangsa; 
g. Melestarikan nilai Pancasila dan kearifan lokal; dan

h. Menyelenggarakan musyawarah dengan kelompok masyarakat untuk membangun kemitraan dengan pelaku usaha di daerah setempat.

4.1.4 Membangun sistem peringatan dini.

a. Penelitian dan pemetaan wilayah potensi konflik;

b. Penyampaian data dan informasi mengenai Konflik secara cepat dan akurat;

c. Penyelenggaraan pendidikan dan pelatihan;

d. Peningkatan dan pemanfaatan modal sosial; dan

e. Penguatan dan pemanfaatan fungsi intelijen sesuai dengan ketentuan peraturan perundang-undangan

\subsection{Penghentian Konflik}

\subsubsection{Penghentian Kekerasan Fisik;}

a. Penghentian kekerasan fisik harus dikoordinasikan dan dikendalikan oleh Polri.

b. Penghentian kekerasan fisik harus melibatkan tokoh masyarakat, tokoh agama, dan/atau tokoh adat.

c. Penghentian kekerasan fisik harus dilakukan sesuai dengan ketentuan peraturan perundang-undangan.

\subsubsection{Penetapan Status Keadaan Konflik}

a. Status keadaan konflik terdiri atas:skala kabupaten/kota;skala provinsi; atauskala nasional.

b. Status keadaan konflik skala kabupaten/kota aadalah bila terjadieskalasi konflik dalam suatu daerah atau wilayahkabupaten/kota dan memiliki dampak hanya pada tingkat kabupaten/kota.

c. Status keadaan konflik skala provinsi bila terjadieskalasi konflik dalam suatudaerah atau wilayah kabupaten/kota dan/atau beberapa kabupaten/kota dalamsuatuprovinsi dan memiliki dampak sampai pada tingkat provinsi.

d. Status keadaan konflikskala nasional bila terjadi eskalasi konflik mencakup suatudaerah atau wilayah kabupaten/kota dan/atau beberapa provinsi dan memiliki dampak secara nasional.

\subsubsection{Tindakan Darurat Penyelamatan dan Perlindungan Korban}


a. Penyelamatan, evakuasi, dan identifikasi korban konflik secara cepat dan tepat;

b. Pemenuhan kebutuhan dasar korban konflik;

c. Pemenuhan kebutuhan dasar pengungsi, termasuk kebutuhan spesifik perempuan, anak-anak, dan kelompok orang yang berkebutuhan khusus;

d. Pelindungan terhadap kelompok rentan;

e. Upaya sterilisasi tempat yang rawan konflik;

f. Penyelamatan sarana dan prasarana vital;

g. Penegakan hukum;

h. Pengaturan mobilitas orang, barang, dan jasa dari dan ke daerah Konflik; dan

i. Penyelamatan harta benda korban konflik.

\subsubsection{Bantuan Penggunaan dan Pengerahan Kekuatan TNI.}

a. Dalam status keadaan konflik skala kabupaten/kota, bupati/wali kota dapat meminta bantuan penggunaan kekuatan TNI kepada Pemerintah.

b. Dalam status keadaan konflik skala provinsi, gubernur dapat meminta bantuan penggunaan kekuatan TNI kepada Pemerintah.

c. Dalam status keadaan konflik skala nasional, Presiden berwenang mengerahkan kekuatan TNI setelah berkonsultasi dengan pimpinan DPR.

d. Bantuan penggunaandan pengerahan kekuatan TNI sebagaimana dimaksud diatas harusdilakukan sesuai dengan ketentuan peraturan perundangundangan.

\subsection{Pemulihan Pascakonflik}

4.3.1 Rekonsiliasi

a. Perundingan secara damai;

b. Pemberian restitusi; dan/atau

c. Pemaafan.

d. Rekonsiliasi sebagaimana dimaksud diatas dapat dilakukan dengan Pranata Adat dan/atau Pranata Sosial atau Satuan Tugas Penyelesaian Konflik Sosial.

\subsubsection{Rehabilitasi}

a. Pemulihan psikologis korban Konflik dan pelindungan kelompok rentan;

b. Pemulihan kondisi sosial, ekonomi, budaya, keamanan, dan ketertiban;

c. Perbaikan dan pengembangan lingkungan dan/atau daerah perdamaian; 
d. Penguatan relasi sosial yang adil untuk kesejahteraan masyarakat;

e. Penguatan kebijakan publik yang mendorong pembangunan lingkungan dan/atau daerah perdamaian berbasiskan hak masyarakat;

f. Pemulihan ekonomi danhak keperdataan, serta peningkatan pelayanan pemerintahan;

g. Pemenuhan kebutuhan dasar spesifik perempuan,anak-anak, lanjut usia, dan kelompok orang yang berkebutuhan khusus;

h. Pemenuhan kebutuhan dan pelayanan kesehatan reproduksi bagi kelompok perempuan;

i. Peningkatan pelayanan kesehatan anak-anak; dan pemfasilitasian serta mediasi pengembalian dan pemulihan aset korban konflik.

\subsubsection{Rekonstruksi}

a. Pemulihan dan peningkatan fungsi pelayanan publik di lingkungan dan/atau daerah pascakonflik;

b. Pemulihan dan penyediaan akses pendidikan, kesehatan, dan mata pencaharian;

c. Perbaikan sarana dan prasarana umum daerah konflik;

d. Perbaikan berbagai struktur dan kerangka kerja yang menyebabkan ketidaksetaraan dan ketidakadilan, termasuk kesenjangan ekonomi;

e. Perbaikan dan penyediaan fasilitas pelayanan pemenuhan kebutuhan dasar spesifik perempuan, anak-anak, lanjut usia, dan kelompok orang yang berkebutuhan khusus;

f. Perbaikan dan pemulihan tempat ibadah.
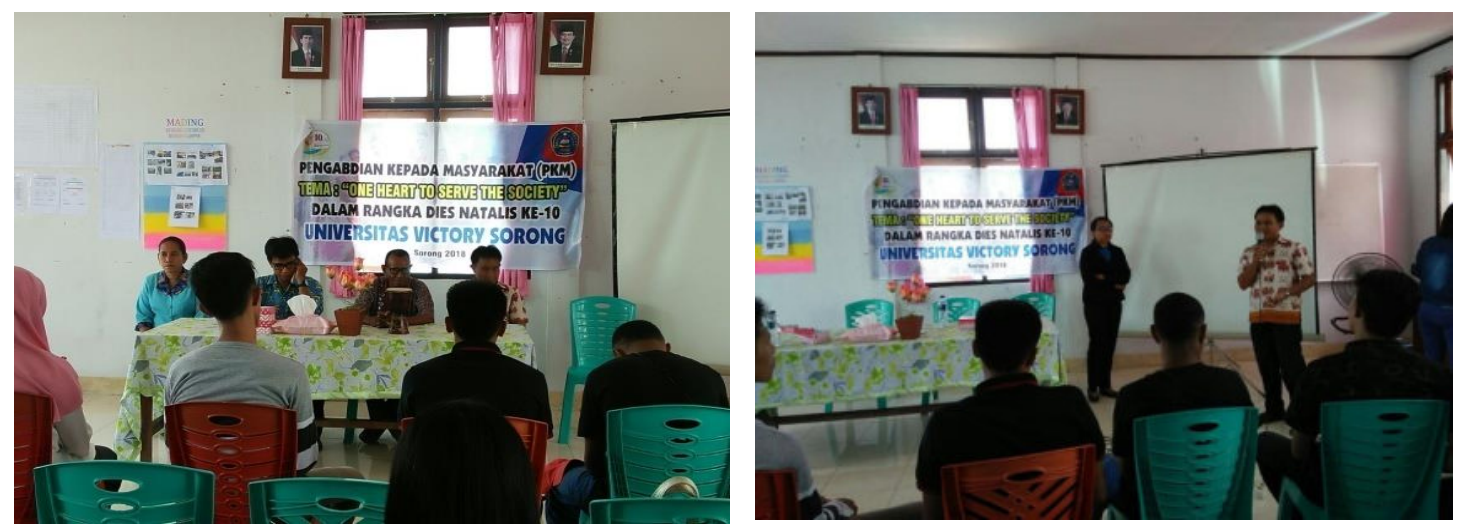

Gambar 1. Suasana Sosialisasi Penanganan Konflik Sosial 


\section{KESIMPULAN}

Berdasarkan perbandingan antara hasil studi pendahuluan dengan pemaparan (pendalaman) materi, nampak bahwa ada perbedaan yang signifikan dari sebelumnya belum ada pemahaman, kini jauh lebih memahami tentang penanganan konflik sosial. Hal ini dapat dilihat dari hidupnya ruang tanya jawab dan bahkan lebih dari itu sangat antusias dalam forum curah pendapat. Bahkan selama ini, konflik yang muncul itu dianggap sebagai sesuatu keniscayaan (hal yang tidak boleh terjadi) didalam berinteraksi dengan sesama.

Diharapkan setelah mengikuti penyuluhan dan/atau penyampaian materi dimaksud maka khalayak sasaran memperoleh pemahaman dan pengetahuan yang komprehensif dan terintegral mengenai penanganan konflik sosial secara baik dan benar. Selain itu, mereka menyadari bahwa konflik itu selalu ada, karena adanya perbedaan kepentingan ekonomi, agama, politik, etnis, budaya dan lain-lain, sehingga, konflik hanya dapat dikelola/dikontrol dengan pendekatan yang humanis namun tegas sesuai intensitas konflik yang ada. Dengan demikian, intensitas konflik dapat dikendalikan agar tercipta hubungan harmonis diantara pihak yang berkonflik. Adapun cakupan materi dalam penyuluhan mengenai konflik sosial, adalah meliputi pencegahan konflik; penghentian konflik; dan pemulihan pascakonflik.

\section{DAFTAR PUSTAKA}

Anonim. (2011). Pusat Studi Pedesaan dan Kawasan. Yogyakarta:UGM.

Bakker, Anton.( 1984). Metode-Metode Filsafat. Ghalia Indonesia. Cetakan Pertama. Jakarta. Indonesia.

Bernstein, J. (1981). The Problem of Style, Theory, Culture and Society.Oxford.

Fowler, James W. (1976).Stage of Faith.The Psychology of Human Development and the Quest for Meaning. San Fransisco. Harper \& Row Publishers.

Giay, Benny. (1995). Masyarakat Amungme (Irian Jaya), Modernisasi dan Agama Resmi: Sebuah Pertemuan .Uncen.Jayapura. 